\title{
Gender differences in clinical features and complications of infective endocarditis: 11- year experience of a single institute in Egypt
}

\author{
Ahmed Adel Elamragy ${ }^{1 *}$ (D, Marwa Sayed Meshaal ${ }^{1}$, Amani Ali El-Kholy ${ }^{2}$ and Hussein Hassan Rizk ${ }^{1}$
}

\begin{abstract}
Background: No data exists about the gender differences among patients with infective endocarditis (IE) in Egypt. The objective was to study possible gender differences in clinical profiles and outcomes of patients in the IE registry of a tertiary care center over 11 years.

Results: The IE registry included 398 patients with a median age of 30 years (interquartile range, 15 years); $61.1 \%$ were males. Males were significantly older than females. Malignancy and recent culprit procedures were more common in females while chronic liver disease and intravenous drug abuse (IVDU) were more in males. IE on top of structurally normal hearts was significantly more in males $(25.6 \%$ vs $13.6 \%, p=0.005)$ while rheumatic valvular disease was more common in females (46.3\% vs $29.9 \%, p=0.001)$. There was no difference in the duration of illness before presentation to our institution. The overall complication rate was high but significantly higher in females. However, there were no significant differences in the major complications: mortality, fulminant sepsis, renal failure requiring dialysis, heart failure class III-IV, or major cerebrovascular emboli.

Conclusion: In this registry, IE occurred predominantly in males. Females were significantly younger at presentation. History of recent culprit procedures was more common in females while IVDU was more common in males who had a higher incidence of IE on structurally normal hearts. The overall complication rate was higher in women. IE management and its outcomes were similar in both genders.
\end{abstract}

Keywords: Endocarditis, Registries, Gender, Egypt

\section{Background}

Gender differences and their impact on the clinical profile and outcome in cardiovascular diseases are a debatable issue in the literature [1-3]. These differences may be attributed to a variety of factors including variable comorbidities, treatment biases, or inherent physiologic differences [3]. Previous reports addressing this issue in patients with infective endocarditis (IE) did not examine its relationship with outcomes and treatment decisions systematically $[2,3]$. IE occurs in males more frequently than females, with 2:1 to 9:1 ratio [4-6]. Animal models suggested a

\footnotetext{
* Correspondence: ahmed.elamragy@kasralainy.edu.eg

${ }^{1}$ Department of Cardiology, Kasr Al Aini Hospital, Faculty of Medicine, Cairo University, Cairo 11562, Egypt

Full list of author information is available at the end of the article
}

potential protective role for estrogen against endothelial damage $[7,8]$, whereas human studies showed that females less likely develop sepsis after traumatic hemorrhagic shock [9-11], but the exact mechanism is not fully understood. Moreover, females tend to encounter heart disease at an older age than males. Thus, younger females are relatively protected from IE predispositions. On the other hand, females have a higher incidence of comorbid conditions (e.g., diabetes mellitus (DM) and renal failure) which may complicate IE management and result in worse outcomes [12].

In Egypt, no data exists about the gender differences among patients with IE regarding clinical characteristics or prognosis. Gender biases in offering diagnostic and treatment services are alleged in rural and underprivileged areas. 


\section{Methods}

\section{Patient cohort}

An IE specialized unit and registry were established in February 2005 in a tertiary care facility in Egypt to define the clinical profile of IE patients and improve the awareness and management of this disease entity. The registry details were previously published [13], including definitions of terms used (prosthetic valve endocarditis (PVE), intravenous drug use (IVDU)-associated IE and healthcare-associated endocarditis (HAE)), the microbiologic data (blood cultures, serologic tests, surgical specimen cultures, and histopathologic examination), and follow-up during the hospital course. The current study involves all patients with possible/definite IE [14] between February 2005 and September 2016. Transthoracic echocardiography (TTE) was performed within 24$48 \mathrm{~h}$ of hospital admission followed by trans-esophageal echocardiography (TEE) within another $72 \mathrm{~h}$ if there was a clinical indication [13]. All patients received the appropriate management protocols as recommended by the current guidelines [15-21]. Patient education on IE prophylaxis, dental care, and symptoms and signs of IE recurrence was provided upon discharge. In addition to regular patient care, the dedicated IE team organized regular meetings and seminars, distributed brochures about proper IE diagnosis and management, and arranged infection control workshops on proper blood and tissue sampling techniques. Besides, regular internal and external audit meetings were held to monitor the progress of the IE registry [13].

\section{Statistical analysis}

Data analysis was performed by SPSS 20.0 program. Categorical data were expressed as percentages. Continuous variables were skewed and presented as median and interquartile range (IQR). Differences in categorical variables were tested by the chi-squared test or Fisher's exact (when appropriate). The comparison of continuous variables was done using the Mann-Whitney test. Gender-specific significant univariate variables for inhospital mortality (with $p<1.0$ ) entered a stepwise conditional multivariate regression analysis to detect the most significant independent predictors with the corresponding odds ratio (OR) and 95\% confidence interval (CI). Statistical significance was considered at $p<0.05$.

\section{Results}

\section{Clinical characteristics}

The patient cohort included 398 patients; median age, 30 years (IQR, 24-39 years), 61.1\% were males. The main clinical features and comorbidities are demonstrated in Table 1. Males were significantly older than females. Malignancy and recent culprit procedures were more common in females while chronic liver disease and
Table 1 Clinical characteristics based on gender

\begin{tabular}{|c|c|c|c|}
\hline & $\begin{array}{l}\text { Males }(n=243), \\
N(\%)\end{array}$ & $\begin{array}{l}\text { Females }(n=155) \\
N(\%)\end{array}$ & $p$ \\
\hline Age (years) & $31(24-40)$ & $28(23-37)$ & 0.002 \\
\hline \multicolumn{4}{|l|}{ Comorbid conditions } \\
\hline DM & $13(5.3)$ & $7(4.5)$ & 0.71 \\
\hline Renal insufficiency & $28(11.5)$ & $19(12.3)$ & 0.83 \\
\hline Liver disease & $14(5.5)$ & $0(0)$ & 0.001 \\
\hline Malignancy & $0(0)$ & $7(4.5)$ & 0.001 \\
\hline \multicolumn{4}{|l|}{ Clinical history } \\
\hline Fever & $198(81.5)$ & $137(88.4)$ & 0.07 \\
\hline $\begin{array}{l}\text { Duration of febrile } \\
\text { illness }\end{array}$ & $28(14-60)$ & $28(12-56)$ & 0.76 \\
\hline $\begin{array}{l}\text { Previous use of } \\
\text { antibiotics }\end{array}$ & $146(60.1)$ & $85(54.8)$ & 0.30 \\
\hline Prior IE & $12(4.9)$ & $3(1.9)$ & 0.13 \\
\hline Drug abuse & $40(16.5)$ & $2(1.3)$ & $<0.001$ \\
\hline HAE & $105(44.9)$ & $80(54.4)$ & 0.069 \\
\hline $\begin{array}{l}\text { Procedures within } \\
\text { the last } 3 \text { months }\end{array}$ & 49 (20.9) & $46(31.3)$ & 0.023 \\
\hline $\begin{array}{l}\text { Hospitalization within } \\
\text { the last } 3 \text { months }\end{array}$ & $85(36.3)$ & $66(44.9)$ & 0.096 \\
\hline $\begin{array}{l}\text { Underlying cardiac } \\
\text { disease }\end{array}$ & $147(60.5)$ & $108(69.7)$ & 0.06 \\
\hline $\begin{array}{l}\text { Rheumatic heart } \\
\text { disease }\end{array}$ & $70(29.9)$ & $68(46.3)$ & 0.001 \\
\hline $\begin{array}{l}\text { Congenital heart } \\
\text { disease }\end{array}$ & $24(10.3)$ & $8(5.4)$ & 0.099 \\
\hline $\begin{array}{l}\text { Degenerative valve } \\
\text { disease }\end{array}$ & $7(3.0)$ & $3(2)$ & 0.57 \\
\hline Normal heart & $60(25.6)$ & $20(13.6)$ & 0.005 \\
\hline $\begin{array}{l}\text { Hypertrophic } \\
\text { cardiomyopathy }\end{array}$ & $3(1.3)$ & $0(0)$ & 0.29 \\
\hline PVE & $69(28.4)$ & $47(30.3)$ & 0.68 \\
\hline
\end{tabular}

$D M$ diabetes mellitus, IE infective endocarditis, HAE healthcare-associated IE, PVE Prosthetic valve endocarditis

IVDU were more in males. There was a trend for higher HAE in females. However, the various culprit procedures did not differ between both genders (intravenous lines, early PVE, dialysis, non-cardiac surgeries, dental procedures, or urinary catheter insertions). IE on top of structurally normal hearts was significantly more prevalent in males while rheumatic heart disease (RHD) was more common in females. The duration of illness before presentation to our institution was very long and did not differ between both genders.

\section{Echocardiographic findings}

The main echocardiographic features are represented in Table 2. Left-sided vegetation (mitral and aortic valves) and development of ring abscesses were more common 
Table 2 Echocardiographic features of both genders

\begin{tabular}{|c|c|c|c|}
\hline & $\begin{array}{l}\text { Males }(n=243), \\
N(\%)\end{array}$ & $\begin{array}{l}\text { Females }(n=155), \\
N(\%)\end{array}$ & $p$ \\
\hline TTE diagnostic & $194(79.8)$ & $120(77.4)$ & 0.57 \\
\hline TEE diagnostic & $121(90.3 \%)$ & $72(91.1 \%)$ & 0.84 \\
\hline Presence of vegetation & $184(75.7)$ & $114(73.5)$ & 0.63 \\
\hline Left-sided vegetation & $138(56.8)$ & $102(65.8)$ & 0.07 \\
\hline $\begin{array}{l}\text { Aortic valve } \\
\text { vegetation TTE }\end{array}$ & $81(33.3)$ & $33(21.3)$ & 0.01 \\
\hline $\begin{array}{l}\text { Mitral valve } \\
\text { vegetation TTE }\end{array}$ & $80(32.9)$ & $79(51)$ & $<0.001$ \\
\hline $\begin{array}{l}\text { Aortic valve } \\
\text { vegetation TEE }\end{array}$ & $57(48.7)$ & $26(40)$ & 0.26 \\
\hline $\begin{array}{l}\text { Mitral valve } \\
\text { vegetation TEE }\end{array}$ & $66(55.9)$ & $51(65.4)$ & 0.19 \\
\hline $\begin{array}{l}\text { Aortic valve } \\
\text { vegetation TTE } \\
\text { or TEE }\end{array}$ & $93(65.5)$ & $42(53.2)$ & 0.07 \\
\hline $\begin{array}{l}\text { Mitral valve } \\
\text { vegetation TTE } \\
\text { or TEE }\end{array}$ & $101(69.2)$ & $99(81.8)$ & 0.018 \\
\hline Right sided vegetation & $53(21.8)$ & $15(9.7)$ & 0.002 \\
\hline $\begin{array}{l}\text { Pulmonary valve } \\
\text { vegetation }\end{array}$ & $3(1.2)$ & $3(1.9)$ & 0.58 \\
\hline $\begin{array}{l}\text { Tricuspid valve } \\
\text { vegetation }\end{array}$ & $48(19.8)$ & $14(9)$ & 0.004 \\
\hline Ring abscess & $32(22.4)$ & $20(12.9)$ & 0.03 \\
\hline Pericardial effusion & $49(20.2)$ & $36(23.2)$ & 0.47 \\
\hline
\end{tabular}

TIE transthoracic echocardiography, TEE trans-esophageal echocardiography

in females, whereas right-sided vegetation (namely the tricuspid valve) was more common in males.

\section{Microbiologic data}

The rate of negative blood cultures was equally high in males and females $(69.5 \%$ vs $68.4 \%, p=0.8)$, and there were no gender differences in the rate of organism detection using different methods (surgical specimen culture and histology). The most common detected organisms were staphylococcal species $(28.8 \%$ vs $21.3 \%$, $p=0.1)$. There were no gender differences in all other detected organisms (streptococci, enterococci, gramnegative bacilli, fungi, or zoonotic organisms). Empirical antibiotics were also equally given in both genders (59.3\% vs $55.5 \%, p=0.5)$.

\section{Complications}

The overall complication rate was high, but it was significantly higher in females. However, the major complications (fulminant sepsis, renal failure requiring dialysis, advanced heart failure, major cerebrovascular stroke, and in-hospital mortality) were similar between both genders. Surgery was equally performed when clinically indicated (Figs. 1 and 2)
Predictors of in-hospital mortality in both genders

Univariate predictors of in-hospital mortality are presented in Table 3. Using multivariate analysis, the most important predictors of in-hospital mortality in males were poor response to antibiotics (OR, 57.0; CI, 12.7-269.1, $p<0.001$ ), fulminant sepsis (OR, 10.8; 95\% CI, 1.2-98.2; $p=0.034)$, and not performing surgery when indicated (OR, 8.9; 95\% CI, 3.5-23.0; $p$ $<0.001)$. In females, poor response to antibiotics was the sole predictor of in-hospital mortality (OR, 15.1; 95\% CI, 1.5-161.0; $p=0.022$ ).

\section{Discussion}

This is a subgroup analysis of an IE registry in a tertiary care facility for 11 years in which we studied the main differences in IE features and management between both genders. The main registry report and subgroup reports were previously published [13, 22-28]. Differences in offering diagnostic and therapeutic healthcare services based on gender have been a major worldwide concern over the years [29-32]. In this analysis, there were no gender differences in the management and outcome of IE patients. The response to antibiotic treatment, the need for surgical treatment, the rate of surgical interventions, and overall in-hospital mortality were similar in both genders. Previous IE studies showed worse outcomes among females [1, 33, 34], because of less surgical interventions in the active phase of the disease [34] or comorbid conditions that put females at a higher risk $[1,3]$.

Comorbid conditions like DM and renal insufficiency were not different between both genders. However, males suffered more from liver diseases, while females had a higher incidence of malignancy. This contrasts with a previous study [3] which showed a higher prevalence of DM, renal insufficiency, and immunosuppression among females that was translated into a worse outcome. Another study [1] also showed that renal insufficiency and immunosuppression were more common in females.

We previously reported a high rate of overall complications (39.4\%) [13]. A striking feature was the significantly higher rate among females that can be attributed to the trend of higher rates of HAE which translates to highly resistant strains. Fortunately, the major lifethreatening complications (advanced heart failure, fulminant sepsis, renal failure, major cerebrovascular emboli, and in-hospital mortality) did not differ between both genders. This is in contrast to a previous study [3] that showed a twofold higher rate of in-hospital mortality among females, explained by the presence of more comorbid conditions. The same study and another one [34] also showed a higher rate of surgical interventions among males. In our registry, the rate of performing 


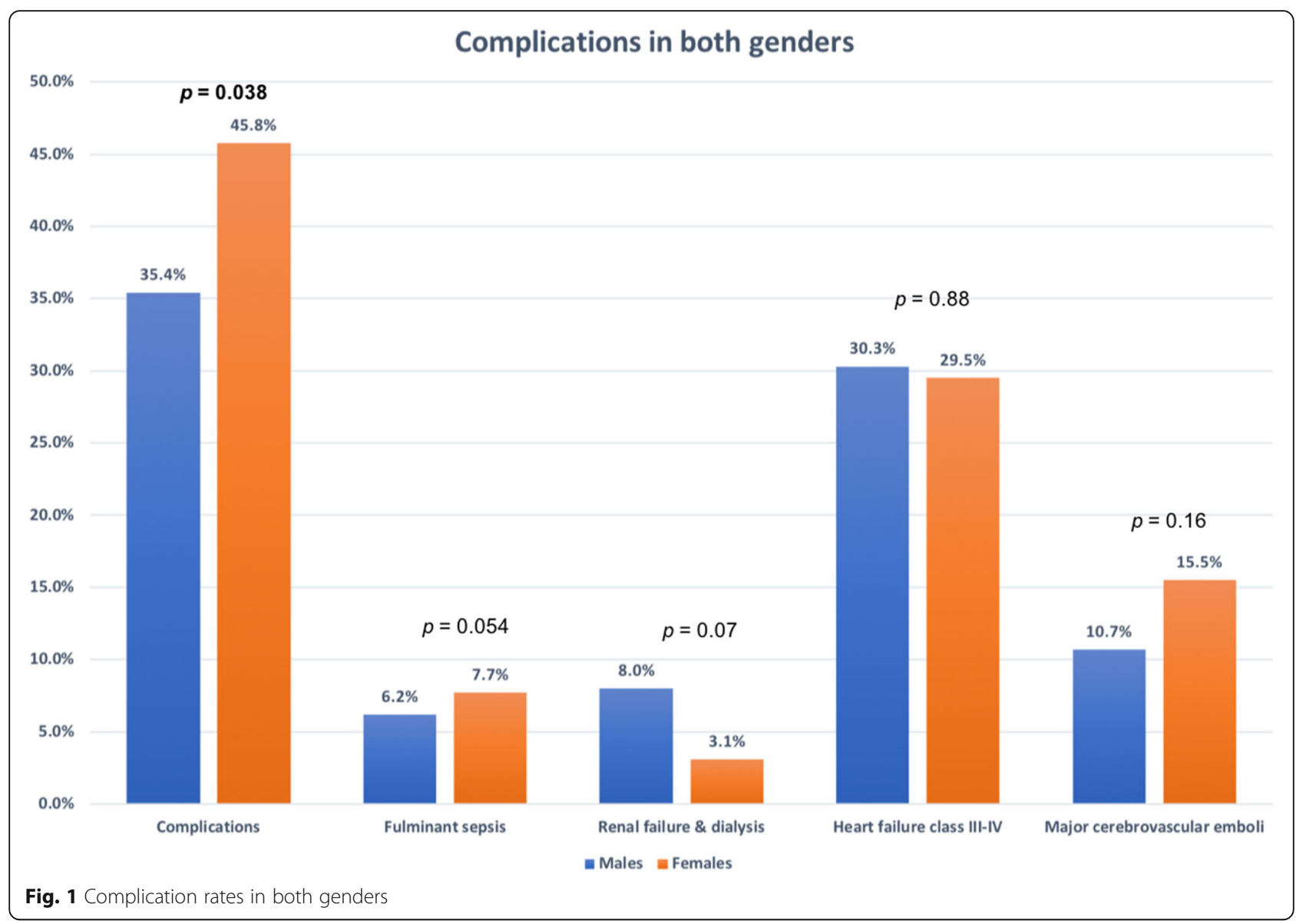

surgery when indicated, the use of antibiotics, and the overall outcome were similar between both genders. This confirms the absence of gender-bias in offering medical services in our facility.

In our registry, IE occurred more commonly in males (61.1\%) with a ratio of 1.6:1. This gender predilection for IE was previously reported in Saudi Arabia [35], United Kingdom (UK) [36], Japan [37], and other reports [4-6]. There are theories about a potential protective role for estrogen against endothelial damage $[7,8]$ and a less likelihood of developing sepsis in females [9-11], but the exact mechanism is not fully understood.

In this analysis, a history of recent culprit procedures was more common in females, who also had a trend to encounter HAE and a higher incidence of RHD. They are more exposed to health care procedures (concerned with birth control, pregnancy, and labor), which puts them at a higher risk for developing HAE, at a young age, especially when predisposed with high rates of RHD. This may explain the younger age of females with IE in this registry. On the other hand, males had a higher incidence of IE on structurally normal hearts, likely because of a higher incidence of IVDU among them, which can affect normal hearts.
This analysis revealed a very high rate of culturenegative IE (69.1\%) that was equal in both genders. This may be explained by the indiscriminate use of antibiotics for the treatment of any febrile illness before obtaining blood cultures $(58 \%)$. This is a common practice in our country, and it applies to both genders. This rate was also high in African countries like Algeria (56.4\%) [38] and South Africa (55.3\%) [39] compared to European countries like the UK (12.2\%) [40] and France (9\%) [41].

Right-sided valves (namely the tricuspid valve) were more commonly involved among males due to a higher incidence of IVDU. On the other hand, mitral valve involvement (detected by TTE) was more common in females, while aortic valve involvement and the development of aortic ring abscess were more common in males. This finding was previously shown in a study by Hamda et al. [42] and may be explained by the higher rate of mitral disease in females and aortic disease in males [43].

This analysis identified several issues that can be addressed to improve IE management. Medical personnel education about infection control measures and timely management of the various febrile illnesses can be translated into lower rates of HAE, culture-negative IE, and 


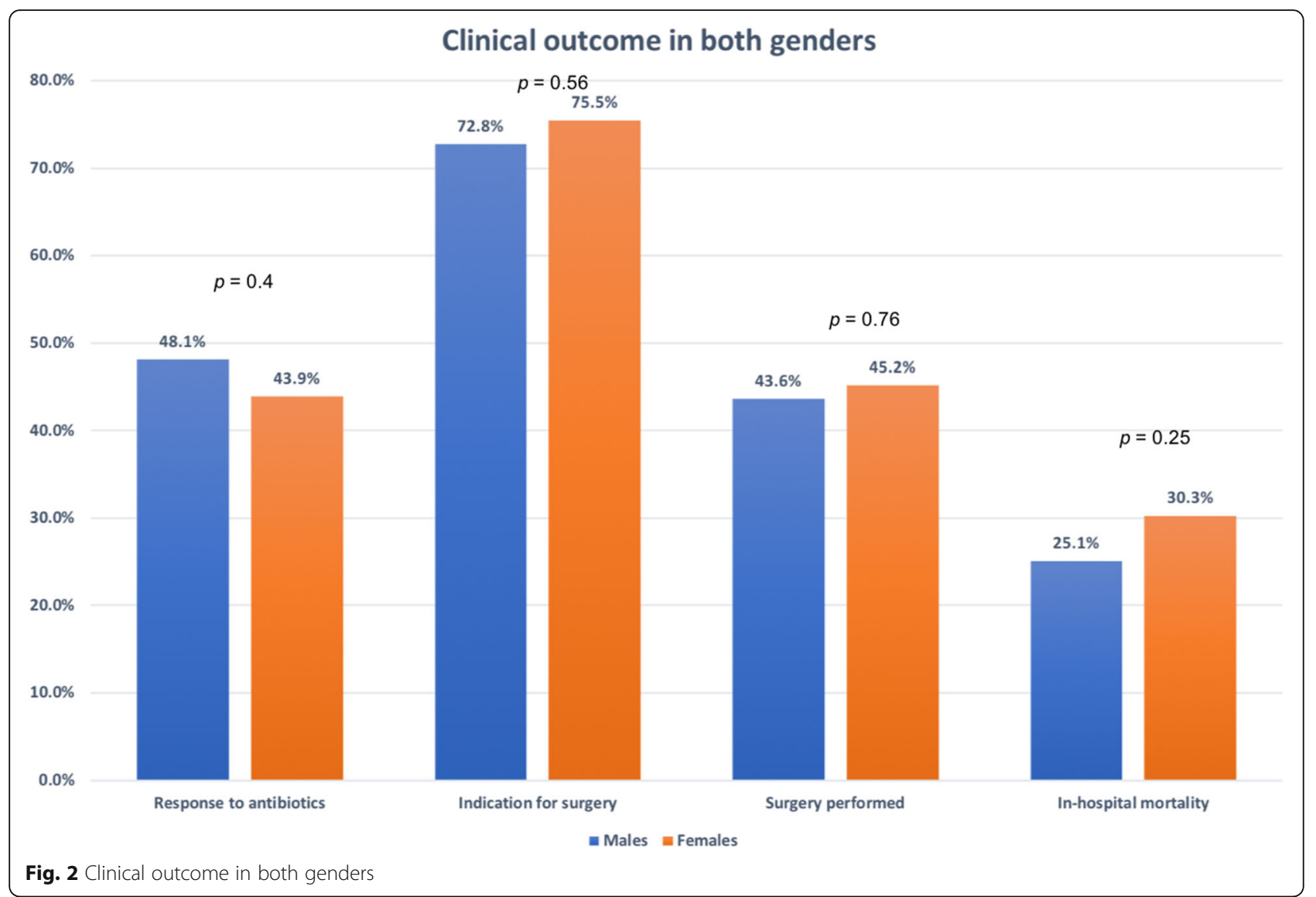

Table 3 Predictors of in-hospital mortality in both genders

\begin{tabular}{|c|c|c|c|c|c|c|}
\hline \multirow[b]{2}{*}{ Univariate analysis } & \multicolumn{3}{|l|}{ Males } & \multicolumn{3}{|l|}{ Females } \\
\hline & Survival, $n=182, N(\%)$ & Mortality, $n=61, N(\%)$ & $p$ & Survival, $n=08, N(\%)$ & Mortality, $n=47, N(\%)$ & $p$ \\
\hline HF NYHA III-IV & $27(14.8)$ & $26(42.6)$ & $<0.001$ & $19(17.6)$ & $19(40.4)$ & 0.002 \\
\hline Fulminant sepsis & $1(0.5)$ & $14(23)$ & $<0.001$ & $1(0.9)$ & $11(23.4)$ & $<0.001$ \\
\hline ARF requiring dialysis & $4(3.4)$ & $10(17.5)$ & 0.002 & $0(0)$ & $4(8.7)$ & 0.015 \\
\hline Poor response to Abs & $68(37.4)$ & $58(95.1)$ & $<0.001$ & $42(38.9)$ & $45(95.7)$ & $<0.001$ \\
\hline Indication for surgery & $125(68.7)$ & $52(85.2)$ & 0.012 & $74(68.5)$ & $43(91.5)$ & 0.002 \\
\hline Indicated surgery not performed & $33(26.4)$ & $38(73.1)$ & $<0.001$ & $22(29.7)$ & $25(58.1)$ & 0.003 \\
\hline Major cerebrovascular emboli & $14(7.7)$ & $12(19.7)$ & 0.009 & $14(13)$ & $10(21.3)$ & 0.188 \\
\hline Embolization & $42(23.1)$ & $27(44.3)$ & 0.001 & $42(38.9)$ & $22(46.8)$ & 0.36 \\
\hline HAE & $70(38.5)$ & $35(57.4)$ & 0.01 & $51(47.2)$ & $29(61.7)$ & 0.097 \\
\hline $\mathrm{RHD}$ & $45(24.7)$ & $25(41)$ & 0.015 & $48(44.4)$ & $20(42.6)$ & 0.83 \\
\hline $\mathrm{ICH}$ & $8(4.4)$ & $8(13.1)$ & 0.017 & $4(3.7)$ & $6(12.8)$ & 0.035 \\
\hline Aortic root abscess & $16(8.8)$ & $5(8.2)$ & 0.89 & $4(3.7)$ & $5(10.6)$ & 0.09 \\
\hline Mycotic aneurysms & $10(5.5)$ & $3(4.9)$ & 1.0 & $5(4.6)$ & $6(12.8)$ & 0.09 \\
\hline Pericardial effusion & $32(17.6)$ & $17(27.9)$ & 0.083 & $24(22.2)$ & $12(25.5)$ & 0.65 \\
\hline Indicated surgery not performed & 8.94 & $3.47-23.04$ & $<0.001$ & & & \\
\hline
\end{tabular}

NYHA New York Heart Association, ARF acute renal failure, Abs antibiotics, HAE healthcare-associated endocarditis, RHD rheumatic heart disease, ICH intracranial hemorrhage, $O R$ odds ratio, $\mathrm{Cl}$ confidence interval 
complications leading to better IE outcomes. Increasing the awareness of the health hazards of IVDU may also decrease the IE infection rates among males.

\section{Conclusion}

In this registry, IE occurred predominantly in males. Females were significantly younger at presentation. History of recent culprit procedures was more common in females while IVDU was more common in males who had a higher incidence of IE on structurally normal hearts. The overall complication rate was higher in women. IE management and its outcomes were similar in both genders.

\section{Abbreviations}

Cl: Confidence interval; DM: Diabetes mellitus; HAE: Healthcare-associated endocarditis; IE: Infective endocarditis; IQR: Interquartile range; IVDU: Intravenous drug use; OR: Odds ratio; PVE: Prosthetic valve endocarditis; RHD: Rheumatic heart disease; TEE: Trans-esophageal echocardiography; TTE: Transthoracic echocardiography; UK: United Kingdom

\section{Acknowledgements}

The authors gratefully acknowledge the valuable input of all the team members of infective endocarditis unit (Dina Osama, Ghada Sayed Youssef, Ahmad Samir, Ahmed ElSharkawy, Karim Said, Hussien Heshmat Kassem, Mervat Gaber Elanany, Al Sayed Akl, Soheir M. Mahfouz, and Khaled Ali Sorour; Departments of Cardiology, Cardiothoracic Surgery, Pathology and Clinical Pathology, Faculty of Medicine, Cairo University) for their valuable contribution in the diagnosis, management, and follow-up of patients in this registry.

\section{Authors' contributions}

AAE and MSM were involved in the diagnosis and management of patients, database entry, and revision, as well as writing the manuscript. HHR was the principal investigator with contributions on the level of supervision, auditing, and reviewing of difficult cases, as well as arranging for seminars and workshops in addition to revision of the manuscript. AAE was responsible for the laboratory workup. All authors have read and approved the manuscript.

\section{Funding}

This research did not receive any specific grant from funding agencies in the public, commercial, or not-for-profit sectors.

\section{Availability of data and materials}

The datasets used and/or analyzed during the current study are available from the corresponding author on reasonable request.

\section{Ethics approval and consent to participate}

This research involved human subjects and was performed in accordance with the Declaration of Helsinki and approved by Cairo University Cardiology Department Ethical Committee. The Committee did not provide a reference number in 2005 (at the time of the beginning of the registry). A written informed consent was obtained from all patients.

\section{Consent for publication}

Not applicable

\section{Competing interests}

The authors declare that they have no competing interests.

\section{Author details}

${ }^{1}$ Department of Cardiology, Kasr Al Aini Hospital, Faculty of Medicine, Cairo University, Cairo 11562, Egypt. ${ }^{2}$ Department of Clinical Pathology and Microbiology, Kasr Al Aini Hospital, Faculty of Medicine, Cairo University, Cairo 11562, Egypt.
Received: 22 November 2019 Accepted: 12 January 2020

Published online: 21 January 2020

\section{References}

1. Sambola A, Fernández-Hidalgo N, Almirante B, Roca I, González-Alujas T, Serra $B$, et al. Sex differences in native-valve infective endocarditis in a single tertiary-care hospital. Am J Cardiol [Internet]. 2010 [cited 2019 Feb 3]; 106(1):92-98. Available from: https://www.sciencedirect.com/science/article/ pii/S0002914910006144

2. Dohmen PM, Binner C, Mende M, Daviewala P, Etz CD, Borger MA et al (2016) Gender-based long-term surgical outcome in patients with active infective aortic valve endocarditis. Med Sci Monit [Internet] 22:2520-2527 Available from: http://www.medscimonit.com/abstract/index/idArt/899360

3. Aksoy O, Meyer LT, Cabell CH, Kourany WM, Pappas PA, Sexton DJ. Gender differences in infective endocarditis: pre- and co-morbid conditions lead to different management and outcomes in female patients. Scand J Infect Dis [Internet]. 2007 [cited 2019 Feb 3];39(2):101-107. Available from: http:// www.tandfonline.com/doi/full/10.1080/00365540600993285

4. Lerner PI, Weinstein $L$ (1966) Infective endocarditis in the antibiotic era. N Engl J Med. 274(5):259-266

5. Watanakunakorn C (1977) Changing epidemiology and newer aspects of infective endocarditis. Adv Intern Med. 22:21-47

6. Cabell CH, Abrutyn E (2003) Progress toward a global understanding of infective endocarditis. Lessons from the International Collaboration on Endocarditis. Cardiol Clin 21(2):147-158

7. Zellweger R, Wichmann MW, Ayala A, Stein S, CM DM, Chaudry IH (1997) Females in proestrus state maintain splenic immune functions and tolerate sepsis better than males. Crit Care Med 25(1):106-110

8. Bakir S, Mori T, Durand J, Chen Y-F, Thompson JA, Oparil S (2000) Estrogeninduced vasoprotection is estrogen receptor dependent. Circulation [Internet]. 101(20):2342-2344 Available from: https://www.ahajournals.org/ doi/10.1161/01.CIR.101.20.2342

9. Oberholzer A, Keel M, Zellweger R, Steckholzer U, Trentz O, Ertel W (2000) Incidence of septic complications and multiple organ failure in severely injured patients is sex specific. J Trauma Inj Infect Crit Care [Internet]. 48(5):932-937 Available from: https://insights.ovid.com/crossref?an=00005373-200005000-00019

10. Wichmann MW, Inthorn D, Andress HJ, Schildberg FW (2000) Incidence and mortality of severe sepsis in surgical intensive care patients: the influence of patient gender on disease process and outcome. Intensive Care Med [Internet]. 26(2):167-172 Available from: http://link.springer.com/10.1007/s001340050041

11. Schröder J (1998) Gender differences in human sepsis. Arch Surg [Internet] 133(11):1200 Available from: http://archsurg.jamanetwork.com/article. aspx?doi=10.1001/archsurg.133.11.1200

12. Moreno R, Zamorano J, Almería C, Villate A, Rodrigo J-L, Herrera D et al (2002) Influence of diabetes mellitus on short- and long-term outcome in patients with active infective endocarditis. J Heart Valve Dis [Internet] 11(5): 651-659 Available from: http://www.ncbi.n/m.nih.gov/pubmed/12358401

13. Rizk HH, Elamragy AA, Youssef GS, Meshaal MS, Samir A, ElSharkawy A et al (2019) Clinical features and outcomes of infective endocarditis in Egypt: an 11-year experience at a tertiary care facility. Egypt Hear J [Internet] 71(1):17 Available from: https:/tehj.springeropen.com/articles/10.1186/s43044-019-0018-y

14. Fournier PE, Casalta JP, Habib G, Messana T, Raoult D. Modification of the diagnostic criteria proposed by the duke endocarditis service to permit improved diagnosis of q fever endocarditis. Am J Med [Internet]. 1996 [cited 2019 Feb 27];100(6):629-633. Available from: http://linkinghub.elsevier.com/ retrieve/pii/S000293439600040X

15. Horstkotte D, Follath F, Gutschik E, Lengyel M, Oto A, Pavie A, et al. guidelines on prevention, diagnosis and treatment of infective endocarditis executive summary: the Task Force on infective endocarditis of the European Society of Cardiology [Internet]. Vol. 25, European Heart Journal. Narnia; 2004 [cited 2019 May 10]. p. 267-76. Available from: https:// academic.oup.com/eurheartj/article-lookup/doi/10.1016/j.ehj.2003.11.008

16. Baddour LM, Wilson WR, Bayer AS, Fowler VG, Bolger AF, Levison ME, et al. Infective endocarditis. Circulation [Internet]. 2005 [cited 2019 Mar 4];111(23). Available from: https://www.ahajournals.org/doi/10.1161/ CIRCULATIONAHA.105.165564

17. Bonow RO, Carabello BA, Chatterjee $K$, de Leon AC, Faxon DP, Freed MD, et al. 2008 focused update incorporated into the ACC/AHA 2006 guidelines for the management of patients with valvular heart disease. J Am Coll Cardiol [Internet]. 2008 [cited 2019 May 10];52(13):e1-142. Available from: https://www. sciencedirect.com/science/article/pii/S0735109708018330?via\%3Dihub 
18. Nishimura RA, Carabello BA, Faxon DP, Freed MD, Lytle BW, O'Gara PT et al (2008) ACC/AHA 2008 guideline update on valvular heart disease: focused update on infective endocarditis. J Am Coll Cardiol [Internet]. 52(8):676-685 Available from: https://linkinghub.elsevier.com/retrieve/pii/S0735109708018354

19. Kearney P, Mokracek A, Butchart E, Hassager C, Uva MS, Miro JM et al (2009) Guidelines on the prevention, diagnosis, and treatment of infective endocarditis (new version 2009): the Task Force on the prevention, diagnosis, and treatment of infective endocarditis of the European Society of Cardiology (ESC). Eur Heart J [Internet]. 30(19):2369-2413 Available from: https://academic. oup.com/eurheartj/article-lookup/doi/10.1093/eurheartj/ehp285

20. Habib G, Lancellotti P, Antunes MJ, Bongiorni MG, Casalta J-P, Del Zotti F, et al. 2015 ESC Guidelines for the management of infective endocarditis. Eur Heart J [Internet]. 2015 [cited 2019 May 10];36(44):3075-3128. Available from: https://academic.oup.com/eurheartj/article-lookup/doi/10.1093/ eurheartj/ehv319

21. Baddour LM, Wilson WR, Bayer AS, Fowler VG, Tleyjeh IM, Rybak MJ et al (2015) Infective endocarditis in adults: diagnosis, antimicrobial therapy, and management of complications. Circulation [Internet]. 132(15):1435-1486 Available from: https://www.ahajournals.org/doi/10.1161/CIR. 0000000000000296

22. Youssef GS, Mashaal MS, El Remisy DR, Sorour KA, Rizk HH. Pericardial effusion in prosthetic and native valve infective endocarditis. Indian Heart J [Internet]. 2019 [cited 2019 Apr 13];71(1):80-84. Available from: https://doi. org/10.1016/j.ihj.2018.12.002

23. Al-Rachidi N, El-Kholy A, Elanany M, Soliman M, Hassan R, Bassiouny D, et al. Early diagnosis of infective endocarditis using a commercial multiplex PCR assay in Egypt. Kasr Al Ainy Med J [Internet]. 2017 [cited 2019 24];23(2):67. Available from: http://www.kamj.eg.net/article.asp?issn=1687-4625;year=201 7; volume $=23 ;$ issue $=2 ;$ spage $=67$; epage $=72$; aulast $=$ Al-Rachidi

24. Meshaal MS, Labib D, Said K, Hosny M, Hassan M, Abd Al Aziz S, et al. Aspergillus endocarditis: diagnostic criteria and predictors of outcome, a retrospective cohort study. Ballotta A, editor. PLoS One [Internet]. 2018 [cited 2019 Apr 14];13(8):e0201459. Available from: https://dx.plos.org/10.13 71/journal.pone.0201459

25. Singer M, Alkady H, Mohsen T, Roushdy A, Akl A, Mashaal M (2017) Predictors of surgical outcome in isolated tricuspid valve endocarditis: single center experience of 60 patients. Thorac Cardiovasc Surg [Internet]. 65(08):634-638 Available from: http://www.thieme-connect.de/DOI/DOI?10.1 055/s-0037-1606386

26. Meshaal MS, Kassem HH, Samir A, Zakaria A, Baghdady Y, Rizk HH (2015) Impact of routine cerebral $C T$ angiography on treatment decisions in infective endocarditis. Hendrikse J, editor. PLoS One [Internet] 10(3): e0118616 Available from: https://dx.plos.org/10.1371/journal.pone.0118616

27. El-Kholy AA, El-Rachidi NGE din, El-Enany MG, AbduRahman EM, Mohamed RM, Rizk HH. Impact of serology and molecular methods on improving the microbiologic diagnosis of infective endocarditis in Egypt. Infection [Internet]. 2015 [cited 2019 Apr 24];43(5):523-529. Available from: http:// www.ncbi.nlm.nih.gov/pubmed/25808262

28. Ammar W, El Aroussi W, El Mahy A, El Kholy A, Rizk H. Case - control study of potential culprit procedures for infective endocarditis in an Egyptian tertiary care center. Egypt Hear J [Internet]. 2013 [cited 2019 Apr 24];65(3): 153-157. Available from: https://www.sciencedirect.com/science/article/pii/ S1110260813000525

29. Stone PH (1996) Influence of race, sex, and age on management of unstable angina and non-Q-wave myocardial infarction: The TIMI III registry. JAMA J Am Med Assoc [Internet]. 275(14):1104-1112 Available from: http:// jama.ama-assn.org/cgi/doi/10.1001/jama.275.14.1104

30. Scirica BM, Moliterno DJ, Every NR, Anderson HV, Aguirre FV, Granger CB et al (1999) Differences between men and women in the management of unstable angina pectoris (the Guarantee Registry). Am J Cardiol [Internet] 84(10):1145-1150 Available from: https://linkinghub.elsevier.com/retrieve/pii/ S0002914999005251

31. Ghali WA, Faris PD, Galbraith PD, Norris CM, Curtis MJ, Saunders LD et al (2002) Sex differences in access to coronary revascularization after cardiac catheterization: importance of detailed clinical data. Ann Intern Med [Internet] 136(10):723 Available from: http://annals.org/article.aspx?doi=10. 7326/0003-4819-136-10-200205210-00007

32. King KM, Ghali WA, Faris PD, Curtis MJ, Galbraith PD, Graham MM et al (2004) Sex differences in outcomes after cardiac catheterization. JAMA [Internet] 291(10):1220 Available from: http://jama.jamanetwork.com/article. aspx?doi=10.1001/jama.291.10.1220
33. Aksoy O, Sexton DJ, Wang A, Pappas PA, Kourany W, Chu V et al (2007) Early surgery in patients with infective endocarditis: a propensity score analysis. Clin Infect Dis. 44(3):364-372

34. Castillo JC, Anguita MP, Delgado M, Ruiz M, Mesa D, Romo E et al (2008) Clinical characteristics and prognosis of infective endocarditis in women. Rev Española Cardiol English Ed [Internet] 61(1):36-40 Available from: https://linkinghub.elsevier.com/retrieve/pii/S1885585708600663

35. Kaki R, Al-Abdullah N. Descriptive epidemiological, clinical and microbiological features of infective endocarditis at a University Hospital in Saudi Arabia. Am J Infect Dis [Internet]. 2019 [cited 2019 Apr 26];14(2):63-68. Available from: https://thescipub.com/abstract/10.3844/ajidsp.2018.63.68

36. Yombi JC, Yuma SN, Pasquet A, Astarci P, Robert A, Rodriguez HV (2017) Staphylococcal versus Streptococcal infective endocarditis in a tertiary hospital in Belgium: epidemiology, clinical characteristics and outcome. Acta Clin Belg [Internet]. 72(6):417-423 Available from: https://www.tandfonline. com/doi/full/10.1080/17843286.2017.1309341

37. Kuijpers JM, Koolbergen DR, Groenink M, Peels KCH, Reichert CLA, Post MC et al (2017) Incidence, risk factors, and predictors of infective endocarditis in adult congenital heart disease: focus on the use of prosthetic material. Eur Heart J. 38(26):2048-2056

38. Benslimani A, Fenollar F, Lepidi H, Raoult D (2005) Bacterial zoonoses and infective endocarditis, Algeria. Emerg Infect Dis 11(2):216-224

39. Koegelenberg CFN (2003) Infective endocarditis in the Western Cape Province of South Africa: a three-year prospective study. QJM [Internet]. 96(3):217-225 Available from: https://academic.oup.com/qjmed/articlelookup/doi/10.1093/qjmed/hcg028

40. Lamas CC (2003) Blood culture negative endocarditis: analysis of 63 cases presenting over 25 years. Heart. 89(3):258-262

41. Hoen B, Alla F, Selton-Suty C, Béguinot I, Bouvet A, Briançon S et al (2002) Changing profile of infective endocarditis: results of a 1-year survey in France. J Am Med Assoc. 288(1):75-81

42. Ben HK, Moatemri F, Hamdi S, Majdoub MA, Denguir H, Bouhadjar A et al (2010) 184 Infective endocarditis in women: clinical characteristics and outcome. Arch Cardiovasc Dis Suppl [Internet] 2(1):59 Available from: https://linkinghub.elsevier.com/retrieve/pii/S1878648010701865

43. Gómez-Doblas JJ (2008) Valvulopatías en la mujer: diferencias de sexo en España. Rev Española Cardiol Supl [Internet]. 8(4):42D-48D Available from: https://linkinghub.elsevier.com/retrieve/pii/S1131358708735647

\section{Publisher's Note}

Springer Nature remains neutral with regard to jurisdictional claims in published maps and institutional affiliations.

\section{Submit your manuscript to a SpringerOpen ${ }^{\circ}$ journal and benefit from:}

- Convenient online submission

- Rigorous peer review

- Open access: articles freely available online

- High visibility within the field

- Retaining the copyright to your article

Submit your next manuscript at $>$ springeropen.com 